\title{
Investigation of the Influence of the Anode Composition of DSA-type Electrodes on the Electrocatalytic Oxidation of Phenol in Neutral Medium
}

\author{
Paula D. P. Alves ${ }^{a}$, Magali Spagnol $^{a}$, Germano Tremiliosi-Filho $^{b}$ and Adalgisa R. de Andrade ${ }^{*, a}$ \\ ${ }^{a}$ Departamento de Química da Faculdade de Filosofia Ciências e Letras de Ribeirão Preto, Universidade de São Paulo, \\ Av. Bandeirantes, 3900, 14040-901 Ribeirão Preto - SP, Brazil \\ ${ }^{b}$ Instituto de Química de São Carlos, Universidade de São Paulo, CP 780, 13560-970 São Carlos - SP, Brazil
}

\begin{abstract}
Neste trabalho a oxidação do fenol foi utilizada como reação modelo para estabelecer uma investigação sistemática da atividade eletrocatalítica de ânodos do tipo ADE com composição nominal $\mathrm{Ti} / \mathrm{Ru}_{0,3} \mathrm{M}_{0,7} \mathrm{O}_{2}$ e Ti//r ${ }_{0,7} \mathrm{M}_{0.3} \mathrm{O}_{2}(\mathrm{M}=\mathrm{Ti}$ and $\mathrm{Sn})$ em $\mathrm{NaClO}_{4} 1,0 \mathrm{~mol} \mathrm{~L}{ }^{-1}$. Nas condições de $\mathrm{VC}$ a oxidação do fenol, independente do material anódico, favorece a polimerização e bloqueia completamente a atividade do eletrodo após poucos ciclos voltamétricos. A seguinte atividade catalítica intrínseca é observada nas condições voltamétricas: $\mathrm{Ti} / \mathrm{Ru}_{0,3} \mathrm{Ti}_{0,7} \mathrm{O}_{2}>>\mathrm{Ti} / \mathrm{Ru}_{0,3} \mathrm{Sn}_{0,7} \mathrm{O}_{2}>\mathrm{Ti} / \mathrm{Ir}_{0,7} \mathrm{Ti}_{0,3} \mathrm{O}_{2}$ $>\mathrm{Ti} / \mathrm{Ir}_{0,7} \mathrm{Sn}_{0,3} \mathrm{O}_{2}$. Entretanto, experimentos de eletrólise $\left(\mathrm{i}=40 / 80 \mathrm{~mA} \mathrm{~cm}{ }^{-2}\right)$ realizados em escala laboratorial mostraram que a escolha apropriada do material anódico pode aumentar consideravelmente a quantidade de $\mathrm{CO}_{2}$ como produto final da eletrólise. Técnicas de CLAE e COT foram utilizadas para quantificar os produtos formados durante as eletrólises. Os materiais anódicos investigados mostraram boa habilidade de oxidação do fenol, redução do COT de $80 \%$ foi atingida para o eletrodo de composição $\mathrm{Ti} / \mathrm{Ru}_{0,3} \mathrm{Ti}_{0,7} \mathrm{O}_{2}$. A benzoquinona formada na primeira hora de eletrólise é consumida gradativamente com o progresso da reação. Ácidos málico, maleico e malônico também foram identificados como sub-produtos da oxidação do fenol.
\end{abstract}

In this paper, phenol oxidation was used as a probe reaction to carry out a systematic investigation of the electrocatalytic activity of DSA-type anodes with nominal compositions equal to Ti/ $\mathrm{Ru}_{0.3} \mathrm{M}_{0.7} \mathrm{O}_{2}$ and $\mathrm{Ti} / \mathrm{Ir}_{0.7} \mathrm{M}_{0.3} \mathrm{O}_{2}(\mathrm{M}=\mathrm{Ti}$ and $\mathrm{Sn})$ in $1.0 \mathrm{~mol} \mathrm{~L}^{-1} \mathrm{NaClO}_{4}$. Under $\mathrm{CV}$ conditions, phenol oxidation favors polymerization that completely blocks the electrode activity after few cycles independently of the anode material. The following intrinsic catalytic efficiency was observed under $\mathrm{CV}$ conditions: $\mathrm{Ti} / \mathrm{Ru}_{0.3} \mathrm{Ti}_{0.7} \mathrm{O}_{2}>>\mathrm{Ti} / \mathrm{Ru}_{0.3} \mathrm{Sn}_{0.7} \mathrm{O}_{2}>\mathrm{Ti} / \mathrm{Ir}_{0.7} \mathrm{Ti}_{0.3} \mathrm{O}_{2}>\mathrm{Ti} / \mathrm{Ir}_{0.7} \mathrm{Sn}_{0.3} \mathrm{O}_{2}$. However, electrolysis experiments $\left(\mathrm{i}=40 / 80 \mathrm{~mA} \mathrm{~cm}^{-2}\right)$ run in laboratory-scale showed that the proper choice of anode material can improve the yields of $\mathrm{CO}_{2}$ as final product. HPLC and TOC techniques were used in order to quantify the electrode efficiency. It is important to emphasize that all anodes presented good ability to oxidize the phenolic portion, and a TOC reduction as high as $80 \%$ was observed for the Ti/ $\mathrm{Ru}_{0.3} \mathrm{Ti}_{0.7} \mathrm{O}_{2}$ electrode. Benzoquinone formed in the beginning of the electrolysis is continuously oxidized as the reaction proceeds. Malic, tartaric and malonic acids were also identified as other byproducts of phenol oxidation.

Keywords: electrocatalysis, phenol, oxidation of organic compounds, oxide coated electrodes

\section{Introduction}

The increase in the waste produced through industrial and domestic activities makes the investigation of alternative routes for the degradation and treatment of hazardous materials imperative. In this context, electrochemical treatments are an alternative to the available treatment technologies e.g., biological, carbon adsorption, thermal incineration, land filling. ${ }^{1-4}$

\footnotetext{
* e-mail: ardandra@ffclrp.usp.br
}

Degradation of organic waste present in many industrial processes e.g., oil refinery, coke plants, high chemical and plastic plants, have been intensively investigated. ${ }^{5-8}$

Phenolic wastes have been classified as one of the priority waste. Present guidelines in Brazil limit phenol concentration in navigation water to $1 \mathrm{ppm}$ and $0.1 \mathrm{ppm}$ for waste discharge. ${ }^{9}$ It is toxic to microorganisms even in very low concentration. Their biodegradation can occur mostly under anaerobic conditions using acclimated population of microorganisms. Phenol has been continuously used as a model compound for waste 
degradation of organic compounds since its oxidation mechanism is well-known. ${ }^{10-14}$ For DSA-type anodes, the electrochemical oxidation of organic compounds occurs together with oxygen evolution reaction (OER). ${ }^{15}$ This is a severe side-reaction which competes with organic oxidation itself and helps to lower the current efficiency of the overall process. ${ }^{16}$ The present challenge is to find conditions where the oxidation of the organic compounds is maximum with minimum OER.

The anode material has a straight relation with the oxidation route followed; i.e., high overpotential materials for OER; e.g. $\mathrm{SnO}_{2}$ and $\mathrm{PbO}_{2}$, referred before as type I anode, favors complete degradation of organic compounds through the formation of $\mathrm{MO}_{x}\left(\mathrm{OH}^{*}\right)$ active sites on the electrode surface. ${ }^{3}$ The mechanism that was proposed in the literature ${ }^{3}$ for the oxidation of an organic compound (R) on these oxides is summarized as indicated below:

$\mathrm{MO}_{\mathrm{x}}+\mathrm{H}_{2} \mathrm{O} \rightarrow \mathrm{MO}_{\mathrm{x}}(\cdot \mathrm{OH})+\mathrm{H}^{+}+\mathrm{e}$

$\mathrm{R}+\mathrm{MO}_{\mathrm{x}}(\cdot \mathrm{OH}) \rightarrow \mathrm{CO}_{2}+\mathrm{MO}_{\mathrm{x}}+\mathrm{H}^{+}+\mathrm{e}$

$\mathrm{MO}_{\mathrm{x}}(\cdot \mathrm{OH}) \rightarrow \frac{1}{2} 2 \mathrm{O}_{2}+\mathrm{MO}_{\mathrm{x}}+\mathrm{H}^{+}+\mathrm{e}$

On the other hand, oxides active for OER; i.e., materials with low overpotential for OER $\left(\mathrm{RuO}_{2}, \mathrm{IrO}_{2}\right.$ and $\left.\mathrm{PtO}_{2}\right)$ produce mild oxidation of organic compounds and are good candidates for a selective synthesis. The following reaction mechanism has been proposed for type II oxides:

$$
\begin{aligned}
& \mathrm{MO}_{\mathrm{x}}+\mathrm{H}_{2} \mathrm{O} \rightarrow \mathrm{MO}_{\mathrm{x}}(\cdot \mathrm{OH})+\mathrm{H}^{+}+\mathrm{e} \\
& \mathrm{MO}_{\mathrm{x}}\left({ }^{\circ} \mathrm{OH}\right) \rightarrow \mathrm{MO}_{\mathrm{x}+1}+\mathrm{H}^{+}+\mathrm{e} \\
& \mathrm{R}+\mathrm{MO}_{\mathrm{x}+1} \rightarrow \mathrm{RO}+\mathrm{MO}_{x} \\
& \mathrm{MO}_{\mathrm{x}+1} \rightarrow 1 / 2 \mathrm{O}_{2}+\mathrm{MO}_{\mathrm{x}}+\mathrm{H}^{+}+\mathrm{e}
\end{aligned}
$$

Considering the environmental problem, the main goal in the design of an electrocatalyst for oxidation of organic compounds is to find non-toxic and low-cost anode materials that achieve best conversion yields to $\mathrm{CO}_{2}$ or at least leads to a TOC amount that is environmentally accepted. Another factor, which may play an important role, is the toxicity of the intermediates formed, which must be kept as low as possible.

Therefore, we propose for the present investigation systematic studies of binary coatings containing mixtures of type I and II oxides in order to understand the catalytic activity of these materials. For this purpose, $\mathrm{TiO}_{2}$ was substituted for $\mathrm{SnO}_{2}$ in the well-known binary ruthenium and iridium dioxide compositions. The following electrode compositions were investigated: $\mathrm{Ti} / \mathrm{Ru}_{0.3} \mathrm{M}_{0.7} \mathrm{O}_{2}$ and Ti/ $\operatorname{Ir}_{0.7} \mathrm{M}_{0.3} \mathrm{O}_{2}(\mathrm{M}=\mathrm{Ti}$ and $\mathrm{Sn})$. The anode efficiency is discussed on the basis of mild (CV) and strong (galvanostatic polarization) electrochemical conditions.

\section{Experimental}

\section{Electrode preparation}

Electrodes were prepared through thermal decomposition $\left(\mathrm{T}_{\text {calcination }}=450^{\circ} \mathrm{C}\right)$ under oxygen flux $(5 \mathrm{~L}$ $\left.\mathrm{min}^{-1}\right)$. Ti-supported oxide layers with nominal compositions equal to $\mathrm{Ti} / \mathrm{Ru}_{0.3} \mathrm{Ti}_{0.7} \mathrm{O}_{2}, \mathrm{Ti} / \mathrm{Ru}_{0.3} \mathrm{Sn}_{0.7} \mathrm{O}_{2}$ and $\mathrm{Ti} / \mathrm{Ir}_{0.7} \mathrm{Ti}_{0.3} \mathrm{O}_{2}$ were prepared through the standard method, ${ }^{17,18}$ where the appropriate precursor mixture of chloride solutions in $\mathrm{HCl}$ 1:1 (v/v) (Merck) was used. The following salts were used: $\mathrm{RuCl}_{3} \cdot n \mathrm{H}_{2} \mathrm{O}$ (Aldrich); $\mathrm{IrCl}_{3}$ $n . \mathrm{H}_{2} \mathrm{O}$ (Aldrich); $\mathrm{TiCl}_{4}$ (Vectron) and $\mathrm{SnCl}_{2} \cdot 2 \mathrm{H}_{2} \mathrm{O}$ (Merck).

Previous results have showed that coatings containing a mixture of iridium and tin oxides prepared in acidic aqueous medium furnished low yields of $\mathrm{SnO}_{2} \cdot{ }^{19}$ The standard method failed to obtain a proper control of composition either due to the low boiling point of the tinprecursor ${ }^{20}$ or due to volatilization of $\mathrm{SnCl}_{4}$ formed during the calcination processes..$^{19}$ Therefore, in order to overcome Sn-loss, the $\mathrm{Ti} / \mathrm{Ir}_{0.7} \mathrm{Sn}_{0.3} \mathrm{O}_{2}$ electrode was prepared through an alternative route, which is based in the decomposition of a polymeric precursor solution. ${ }^{21,22}$ The polymeric solution of tin was prepared by mixing citric acid (CA) (Merck) in ethylene glycol (EG) (Merck) at $65^{\circ} \mathrm{C}$. After total dissolution of CA, the temperature was raised to $90{ }^{\circ} \mathrm{C}$ and tin citrate (TC), prepared as described elsewhere, ${ }^{23}$ was then added. The molar ratio CA:EG:TC in the resin was 3:10:1. Iridium was introduced in the resin by adding the appropriate amount of $\mathrm{IrCl}_{3} n \cdot \mathrm{H}_{2} \mathrm{O}$ solution $\left(0.2 \mathrm{~mol} \mathrm{~L}^{-1}\right)$.

The precursor's mixtures were applied to the pre-treated metal support by brushing. ${ }^{18}$ The solvents were evaporated at low temperature $\left(80-90^{\circ} \mathrm{C}\right)$ and the dried layer was fired in a pre-heated oven at $450{ }^{\circ} \mathrm{C}$ for $10 \mathrm{~min}$, under a $5 \mathrm{~L}^{-1}$ $\min ^{-1} \mathrm{O}_{2}$-flux. The previous steps were repeated until the desired nominal oxide loading ( $\phi=2 \mu \mathrm{m}$, nominal) was reached $\left(\approx 1.25 \mathrm{mg} \mathrm{cm}^{-2}\right)$. The layers were finally annealed for 1 hour under $\mathrm{O}_{2}$-flux. The electrode mounting was prepared as described elsewhere. ${ }^{17}$

The surface morphology, microstructure and elemental composition of the $\mathrm{Ti} / \mathrm{Ir}_{0.7} \mathrm{Sn}_{0.3} \mathrm{O}_{2}$ electrode were analyzed through scanning electron microscopy (SEM) and energy dispersive X-ray spectroscopy (EDS) in a Leica-Zeiss LEO 440 model SEM coupled to an Oxford 7060 model analyzer.

\section{Reagents}

All chemicals were of analytical grade and were used without further purification. Milli-Q quality (Millipore) water was used. Studies were carried out using $1.0 \mathrm{~mol} \mathrm{~L}^{-1}$ $\mathrm{NaClO}_{4}$ (Carlo Erba). Phenol (Synth) was used as received. 


\section{Electrochemical measurements}

The experimental set up consisted of an EG\&G model 273A potentiostat/galvanostat controlled by a M270 software (EG\&G). Voltammetric experiments were carried out in a three-compartment glass cell of approximately $100 \mathrm{ml}$ in capacity. The anode was mounted in the main compartment; both sides of this electrode were symmetrically placed towards two cathode compartments separated by porous porcelain frits. Two heavy platinized platinum wires were used as counter electrodes. Sodium saturated calomel electrode (SSCE) was used as reference electrode. A magnetic bar provided stirring. The phenol concentration for the cyclic voltammetry experiments ranged from 0 to $30 \mathrm{mmol} \mathrm{L}^{-1}$. Bulk oxidation was carried out under galvanostatic condition (at a fixed $1.0 \mathrm{mmol} \mathrm{L}^{-1}$ phenol concentration) in a divided cell where the cathodic and anodic chambers $(\sim 150 \mathrm{~mL})$ were separated by a Nafion (DuPont) membrane.

\section{Product identification}

Phenol concentration and products formation were sampled through high-pressure liquid chromatography (HPLC) using a Shimadzu LC 10A system at predetermined intervals. The polar oxidation products (carboxylic acids) were analyzed using an Aminex HDX$87 \mathrm{H}$ column with $4 \mathrm{mmol} \mathrm{L}^{-1} \mathrm{H}_{2} \mathrm{SO}_{4}$ as the mobile phase and a refraction index detector. The aromatic intermediates and phenol were also analyzed through HPLC using a Nucleisil C18 (Merck) column, with 60\% metanol: 40\% water as the mobile phase and an UV-Vis detector using a wavelength of $270 \mathrm{~nm}$. The columns temperatures were $30{ }^{\circ} \mathrm{C}$ and the flow rate of the mobile phases was $0.6 \mathrm{~mL} \mathrm{~min}^{-1}$.

The total organic carbon (TOC) in the solution was analyzed on a TOC analyzer (SHIMADZU TOC- 5000A). The method used for TOC analysis was the standard nonpurgable organic carbon (NPOC).

\section{Results and Discussion}

SEM and EDS analysis of the Ti/Ir ${ }_{0.7} \mathrm{Sn}_{0.3} \mathrm{O}_{2}$ electrode prepared through the Pechini method

Figure 1 shows the representative SEM micrograph of a prepared thin film with a nominal composition equal to $\mathrm{Ti} / \mathrm{Ir}_{0.7} \mathrm{Sn}_{0.3} \mathrm{O}_{2}$. The oxide surface presents rough morphology with a mixture of mud-flat cracking containing several micro cracks, generating a high degree of porosity and, large compact regions. As stated before, ${ }^{24}$ the Sn- precursor performs intense modification on the physicalchemical properties of the iridium oxide coatings. By comparing Figure 1 with other SEM micrographs reported for the $\mathrm{Ti} / \mathrm{Ir}_{0.7} \mathrm{Sn}_{0.3} \mathrm{O}_{2}$ composition prepared through different experimental routes, for example sol-gel methodology ${ }^{24}$ or classical thermal decomposition, ${ }^{19}$ it can be seen that polymeric-derived electrodes have intermediate roughness. The EDS analyses performed at random points in the sample indicate that the surface is homogeneous; the obtained experimental Ir/Sn ratio (0.42) shows excellent agreement with the nominal $\mathrm{Ir} / \mathrm{Sn}$ ratio (0.43). This demonstrates that the electrode preparation route followed by us overcame the Sn-volatilization usually reported for mixtures containing $\mathrm{Ir}-\mathrm{Sn} .{ }^{19,24}$ It is believed that the high yields of Sn obtained might be due to the stabilization of the $\mathrm{Sn}$ atoms, which can be fixed in the polyester chain during resin preparation. If one aims to obtain samples with stable contents of $\mathrm{SnO}_{2}$, this might be a good choice if compared to sol-gel routes, once it is much less expensive and simple than the latter one. Our experience also shows that reproducibility of the polymeric precursor route is much more readily obtained.

The SEM performed for Ir, Sn and Ti for a side section of the film shows that the experimental thickness of the coating has an average value of $18 \mu \mathrm{m}$, which is nine times higher than the nominal one controlled through the weight process. The dots map for the horizontal and side sections confirms that Ir and Sn are homogenously distributed in the oxide layer. Neither segregation nor islands with high contents of one metal over another was observed. This result differs from that obtained with the $\mathrm{RuO}_{2}-\mathrm{SnO}_{2}$ coated electrodes prepared through polymeric decomposition method previously investigated by one on us, ${ }^{25}$ which showed that $\mathrm{Sn}$ segregates from $\mathrm{Ru}$ and form regions with Sn-rich deposits.

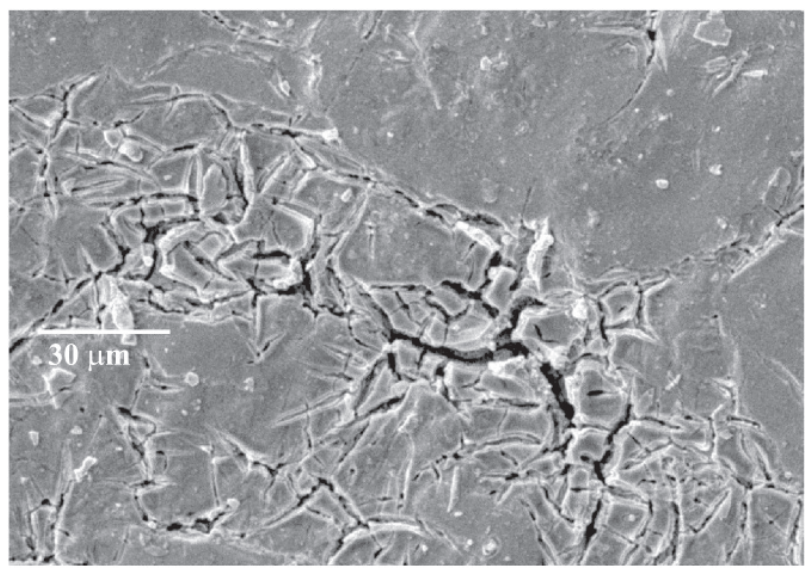

Figure 1. SEM picture of $\mathrm{Ti} / \mathrm{Ir}_{07} \mathrm{Sn}_{03} \mathrm{O}_{2}$ electrode with nominal thick of $2 \mu \mathrm{m} ; \mathrm{T}_{\text {calc }}, 450{ }^{\circ} \mathrm{C} ; \mathrm{O}_{2}$-flux, $5 \mathrm{~L} \mathrm{~min}^{-1}$, amplification of $2000 \mathrm{x}$. 


\section{Cyclic voltammetry in the absence of phenol}

Freshly prepared electrodes were submitted to strong galvanostatic stabilization ( $80 \mathrm{~mA} \mathrm{~cm} /$ one hour) in the electrolyte solution $\left(1.0 \mathrm{~mol} \mathrm{~L}^{-1} \mathrm{NaClO}_{4}\right)$ before the $\mathrm{CV}$ run. Figure 2 shows representative $\mathrm{CV}$ s obtained for freshlyprepared and stabilized electrodes. A meaningful increase in the voltammetric charge is observed that is due to: hydration of internal active sites of the electrode surface ${ }^{26}$ and enhancement of the intrinsic defects of the surface promoted by strong oxygen evolution ${ }^{27}$ can be observed. Moreover, a better definition of the redox-transition state peaks was also observed for the stabilized electrodes.

$\mathrm{CV}$ s obtained for both $\mathrm{Ru}$ and Ir-derived electrodes are in close agreement with what has been previously reported for this medium. ${ }^{28}$ In other words, they show two pairs of broad, not well-defined peaks (I and II), associated to the $\mathrm{Ru}(\mathrm{II}) / \mathrm{Ru}(\mathrm{III})$ and $\mathrm{Ru}(\mathrm{III}) / \mathrm{Ru}(\mathrm{IV})$ solid-state redox transitions for ruthenium-derived electrodes. At potentials higher than $1.0 \mathrm{~V} v s$. SSCE, the current increases due to the beginning of OER (III). For Iridium-oxide electrodes (Figure 2C and D), only the $\operatorname{Ir}(\mathrm{III}) / \mathrm{Ir}(\mathrm{IV})$ solid-state transition is observed (peak IV). The Ti/ $/ \mathrm{Ir}_{0.7} \mathrm{Sn}_{0.3} \mathrm{O}_{2}$ electrode showed less definition of the surface redox process of the catalytic oxide, when compared to its counterpart containing $\mathrm{TiO}_{2}$. A straightforward comparison of these two electrodes is not easy once, besides changes in the modulating metal $(\mathrm{Ti} / \mathrm{Sn})$, the preparation route of iridium electrodes has also been modified. But one can infer that upon changing $\mathrm{TiO}_{2}$ to $\mathrm{SnO}_{2}$, the redox transition $\mathrm{Ir}(\mathrm{III}) /$ Ir(IV) becomes much more spread out over a wide range of potential.

The voltammetric charge is a very sensitive parameter and can be used to translate the electrode "history" i.e., effective coating thickness, composition, calcination temperature and the activation procedure. Although comparing the voltammetric charge of different electrode materials is a difficult task, it was observed that $\mathrm{q}^{*}{ }_{\text {Ir-based }}$ $>\mathrm{q}^{*}{ }_{\text {Ru-based }}$. Changing $\mathrm{TiO}_{2}$ to $\mathrm{SnO}_{2}$ promotes an increase in the apparent roughness of the electrode for both catalytic oxides investigated. Progressive increase in the anodic charge upon $\mathrm{SnO}_{2}$ introduction has been associated with formation of ultra fine particles during the calcination processes. $^{28}$

The apparent roughness factor (RF) for all the electrode compositions was obtained by recording $\mathrm{CV}$ as a function of the sweep rate. From the slope of the linear i vs. $v$ plot (i measured at fixed potentials where pseudo-capacitive current is achieved), RF values were obtained at $0.7 \mathrm{~V} v s$. SSCE for the ruthenium-based electrodes and at 0.8 and $0.9 \mathrm{~V}$ respectively for the $\mathrm{Ti} / \mathrm{Ir}_{0.7} \mathrm{Ti}_{0.3} \mathrm{O}_{2}$ and $\mathrm{Ti} / \mathrm{Ir}_{0.7} \mathrm{Sn}_{0.3} \mathrm{O}_{2}$ compositions. Taking the theoretical capacitance, ${ }^{29} \mathrm{C}^{*}$, of

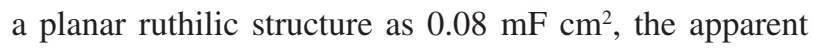
roughness factor $\mathrm{C} / \mathrm{C}^{*}$ shows the following order: $\mathrm{RF}_{\mathrm{IrSn}}$ (3500) $>\mathrm{RF}_{\mathrm{IrTi}}(2400)>>\mathrm{RF}_{\mathrm{RuSn}}(700)>\mathrm{RF}_{\mathrm{RuTi}}(300)$.
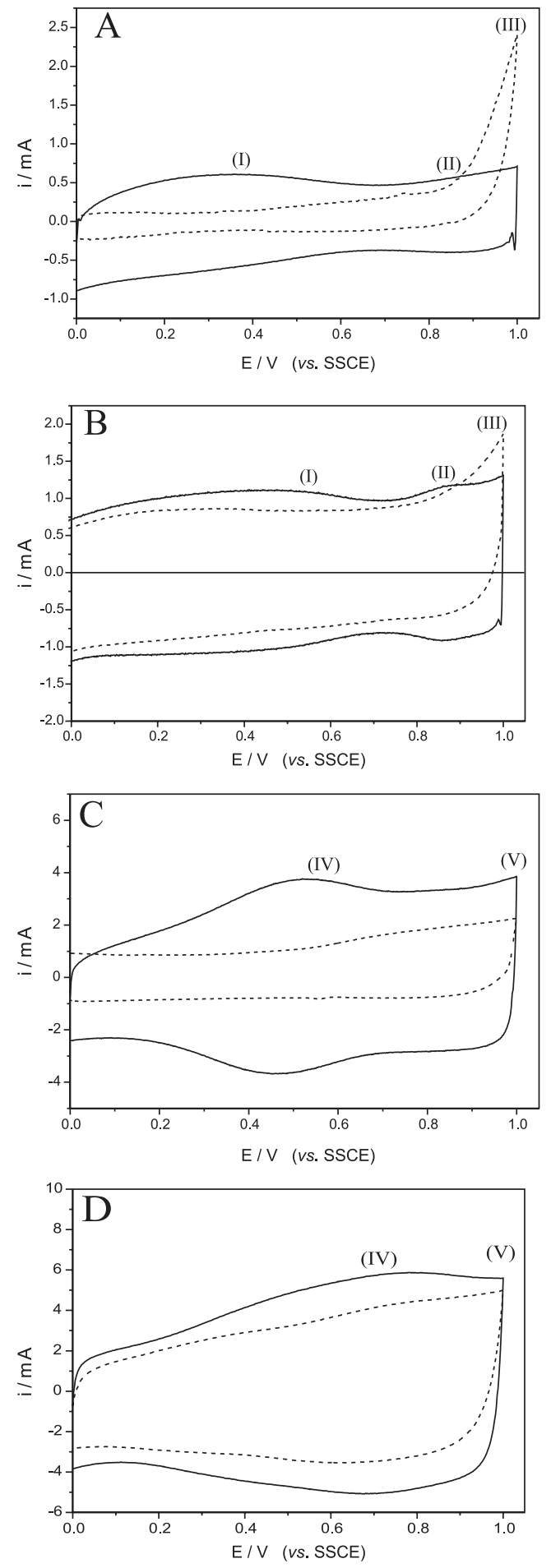

Figure 2. Cyclic voltammograms for different electrode compositions: $\mathrm{Ti} / \mathrm{Ru}_{0.3} \mathrm{Ti}_{0.7} \mathrm{O}_{2}(\mathrm{~A}), \mathrm{Ti} / \mathrm{Ru}_{0.3} \mathrm{Sn}_{0.7} \mathrm{O}_{2}(\mathrm{~B}), \mathrm{Ti} / \mathrm{Ir}_{0.7} \mathrm{Ti}_{0.3} \mathrm{O}_{2}(\mathrm{C})$ and $\mathrm{Ti} / \mathrm{Ir}_{0.7} \mathrm{Sn}_{0.3} \mathrm{O}_{2}$ (D). Before (----) and after (-) conditioning in the supporting electrolyte $\left(1.0 \mathrm{~mol} \mathrm{~L}^{-1} \mathrm{NaClO}_{4}\right) ; v=20 \mathrm{mV} \mathrm{s}^{-1}, \phi=2 \mu \mathrm{m}$, $\mathrm{A}=2 \mathrm{~cm}^{2}, \mathrm{~T}_{\mathrm{cal}}=450{ }^{\circ} \mathrm{C}$. 
The Ru-based electrodes showed that the onset of the OER is highly dependent on the coating composition; the substitution of $\mathrm{TiO}_{2}$ for $\mathrm{SnO}_{2}$ promotes $\sim 60 \mathrm{mV}$ shifts of the overpotential towards less positive values. This is an electric gain introduced by $\mathrm{SnO}_{2}$ and confirms previous results obtained in acid medium that $\mathrm{SnO}_{2}$ is capable of introducing enhancement in the performance of $\mathrm{RuO}_{2}-$ sites. ${ }^{25,30}$ This behavior has been explained as being due to a better segregation of $\mathrm{Ru}$ in $\mathrm{SnO}_{2}$ than in $\mathrm{TiO}_{2}$, leading to a more conductive coating. ${ }^{30}$ For Ir-based electrodes, no appreciable difference was observed by changing the modulate oxide.

Trasatti ${ }^{31}$ has emphasized the concept of "apparent" electrocatalyst, which consists in analyzing the electrode material as a whole i.e., electronic activation plus geometric activation due to an increase in the available surface area of the anode material. Although for academic purpose the first one is always subject of interest, for practical purposes both activations should be considered. Figure 3 shows the plots for current density (i) and its normalized value (i/q*) obtained in neutral medium. When one analyzes the current density which reflects the apparent electrocatalytic effect, it can be observed that for practical purposes the iridium-based electrodes are much more effective for OER than the Ru-based ones. This can be understood as a morphological gain obtained with iridium-based electrodes, which overcome their electronic deficiency. This had been recognized in the industry for the long-term production of oxygen in acid medium by adopting a commercial $\mathrm{Ti} / \mathrm{Ir}_{0.45} \mathrm{Ta}_{0.55} \mathrm{O}_{2}$ electrode composition. Eliminating the morphological factors (i/q*), it is observed that ruthenium-based electrodes show higher "electronic activation" for OER than iridium ones. It is important to show that in neutral medium, the behavior observed is essentially the same reported for acid medium, where the

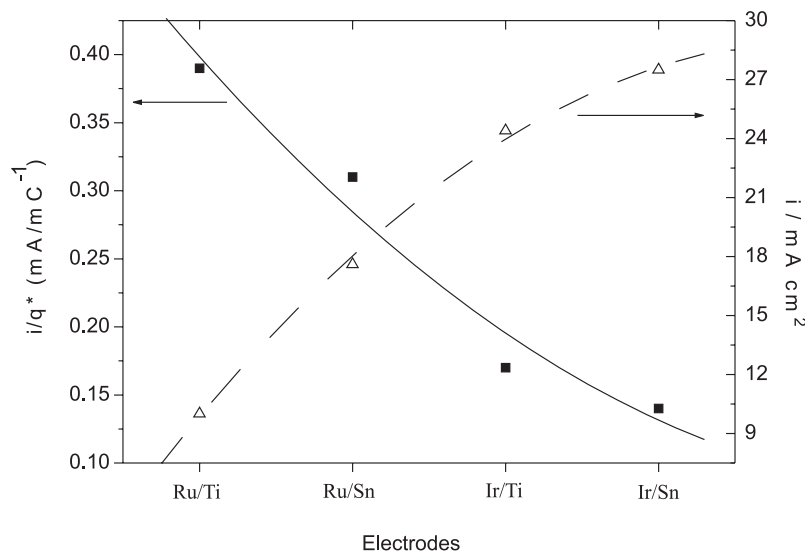

Figure 3. Current density (i) and normalized current density (i/q*) in function of electrode material. Values of $\mathrm{i}$ where measured at a fixed potential $(\mathrm{E}=1.2 \mathrm{~V}$ vs. $\mathrm{SSCE}) ; 1.0 \mathrm{~mol} \mathrm{~L}^{-1} \mathrm{NaClO}_{4}$. ruthenium-derived material is considered to be a much better electronic catalyst than the iridium one. The change of $\mathrm{TiO}_{2}$ to $\mathrm{SnO}_{2}$ in ruthenium-based electrodes gives rise to some interesting features. Analysis of the $\mathrm{i} / \mathrm{q}^{*}$ parameter shows that $\left(\mathrm{i} / \mathrm{q}^{*}\right)_{\mathrm{Ru}-\mathrm{Ti}}>\left(\mathrm{i} / \mathrm{q}^{*}\right)_{\mathrm{Ru}-\mathrm{Sn}}$. Therefore, the better overall activity observed for $\mathrm{Ti} / \mathrm{Ru}_{0.3} \mathrm{Sn}_{0.7} \mathrm{O}_{2}$ may be basically due to morphological changes (area increase) rather than to the enhancement of the electronic activation of the active sites.

\section{Voltammetric behavior in the presence of phenol}

Figure 4 shows a representative $\mathrm{CV}$ for $\mathrm{Ru}$-based electrodes in the presence of phenol. Well-defined oxidation peaks located around 0.8-0.9 V vs. SSCE can be observed. The introduction of $\mathrm{SnO}_{2}$ lowers the overpotential of phenol oxidation by $50 \mathrm{mV}$, in the case of both catalytic oxides. This corroborates with the results obtained for Ru-based electrodes, which showed that switching $\mathrm{TiO}_{2}$ to $\mathrm{SnO}_{2}$ produces more active surfaces. However, despite the fact that iridium-based electrodes do not show any appreciable change in the activity for OER upon $\mathrm{SnO}_{2}$ introduction, they show a worthwhile activation for phenol oxidation. The influence of $\mathrm{SnO}_{x}\left({ }^{\circ} \mathrm{OH}\right)$ active sites on the oxidation of the organic molecule should not be dismissed.

The inset in Figure 4 shows the representative behavior observed as the number of cycles increases. A decrease in the anodic current is observed until it becomes completely blocked after a few cycles. Passivation of electrode surface due to polymeric adhesive products on the electrode surface has been frequently observed ${ }^{32,33}$ and it is mainly related to the low efficiency of the electrode material to perform the total combustion of the organic compounds.

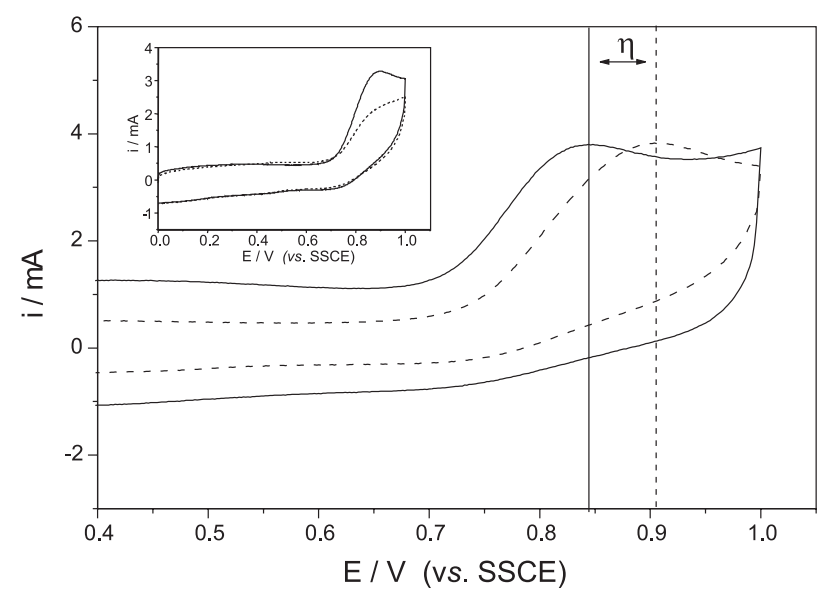

Figure 4. Cyclic voltammograms for phenol oxidation at (---) $\mathrm{Ti} /$ $\mathrm{Ru}_{0.3} \mathrm{Ti}_{0.7} \mathrm{O}_{2}$ and (一) $\mathrm{Ti} / \mathrm{Ru}_{0.3} \mathrm{Sn}_{0.7} \mathrm{O}_{2}$ electrodes in $1.0 \mathrm{~mol} \mathrm{~L}^{-1} \mathrm{NaClO}_{4}$. $v=20 \mathrm{mV} \mathrm{s}^{-1} ; \mathrm{C}_{\text {phenol }}=10 \mathrm{mmol} \mathrm{L}^{-1} ; \mathrm{A}=2 \mathrm{~cm}^{2}$. Inset: consecutive run: (-) first scan; (- - ) second scan at $\mathrm{Ti} / \mathrm{Ru}_{0.3} \mathrm{Ti}_{0.7} \mathrm{O}_{2}$. 
Under neutral medium and mild conditions, the reaction mechanism that has been proposed for phenol oxidation is the following: after the first electron transfer, the phenoxy radical forms couples and polymerizes. ${ }^{34}$ This reaction pathway is responsible for electrode deactivation. Transferring the electrode to a cell containing the supporting electrolyte and applying an anodic treatment performs electrochemical re-activation of the electrode surface. Table 1 summarizes the experimental conditions necessary for complete reactivation of the electrode surface. Although electrolysis at low current density is seriously compromised by phenol polymerization, choosing more drastic conditions such as higher overpotentials where simultaneous OER occurs proves to be a good way to overcome this problem.

Table 1. Chronopotenciometric program for electrode cleaning in $\mathrm{NaClO}_{4} 1.0 \mathrm{~mol} \mathrm{~L}^{-1}$

\begin{tabular}{lcc}
\hline & Current density $/ \mathrm{mA} \mathrm{cm}^{-2}$ & time / min \\
\hline $\mathrm{Ti} / \mathrm{Ru}_{0.3} \mathrm{Ti}_{0.7} \mathrm{O}_{2}$ & 40 & 20 \\
$\mathrm{Ti} / \mathrm{R}_{0.3} \mathrm{Sn}_{0.7} \mathrm{O}_{2}$ & 50 & 25 \\
$\mathrm{Ti} / \mathrm{Ir}_{0.7} \mathrm{Ti}_{0.3} \mathrm{O}_{2}$ & 100 & 25 \\
$\mathrm{Ti}^{\mathrm{Ir}} \mathrm{Sn}_{0.7} \mathrm{Sn}_{0.3} \mathrm{O}_{2}$ & 100 & 30 \\
\hline
\end{tabular}

\section{Intrinsic electronic activity for phenol oxidation}

Figure 5 shows the normalized faradaic voltammetric charge of phenol $\left(\mathrm{q}_{\mathrm{phN}}=\left(\mathrm{q}_{\mathrm{ph}}-\mathrm{q}^{*}\right) / \mathrm{q}^{*}\right)$ as a function of phenol concentration and for different electrode compositions. It shows that ruthenium-based electrodes are much more reactive than the respective iridium electrodes. Similar results were also observed when the

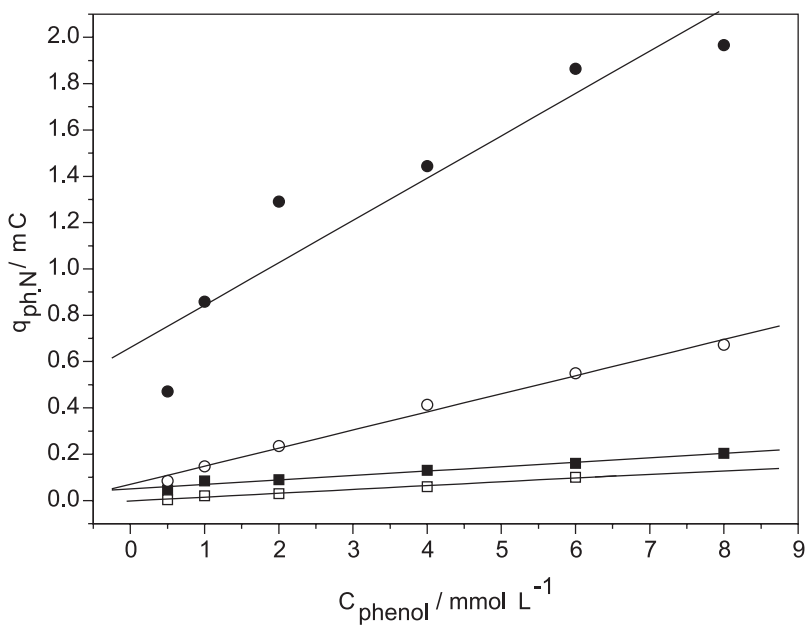

Figure 5. Dependence of normalized charge $\left(\mathrm{q}_{\mathrm{phN}}\right)$ as a function of phenol concentration for different electrode compositions: Ti/ $\mathrm{Ru}_{0.3} \mathrm{Ti}_{0.7} \mathrm{O}_{2}(\bullet) ; \mathrm{Ti} / \mathrm{Ru}_{0.3} \mathrm{Sn}_{0.7} \mathrm{O}_{2}(\mathrm{O}) \mathrm{Ti}^{-} / \mathrm{Ir}_{0.7} \mathrm{Ti}_{0.3} \mathrm{O}_{2}(\boldsymbol{\square})$ and $\mathrm{Ti} /$ $\mathrm{Ir}_{07} \mathrm{Sn}_{03} \mathrm{O}_{2}(\square)$. Electrolyte: $\mathrm{NaClO}_{4} 1.0 \mathrm{~mol} \mathrm{~L}^{-1}, v=20 \mathrm{mV} \mathrm{s}^{-1}$. normalized current-data was analyzed. This confirms that the catalytic efficiency observed for ruthenium oxides is due to their better electronic properties. Previous results obtained in this laboratory for isosafrole oxidation showed the same behavior. ${ }^{35}$ The following intrinsic catalytic efficiency was observed under $\mathrm{CV}$ conditions: Ti/ $\mathrm{Ru}_{0.3} \mathrm{Ti}_{0.7} \mathrm{O}_{2}>>\mathrm{Ti} / \mathrm{Ru}_{0.3} \mathrm{Sn}_{0.7} \mathrm{O}_{2}>\mathrm{Ti} / \mathrm{Ir}_{0.7} \mathrm{Sn}_{0.3} \mathrm{O}_{2} \sim \mathrm{Ti} /$ $\mathrm{Ir}_{0.7} \mathrm{Ti}_{0.3} \mathrm{O}_{2}$.

\section{Electrolysis and product analysis}

Figure 6 shows that, when the current density is maintained at $40 \mathrm{~mA} \mathrm{~cm}^{-2}$, the profile of phenol normalized concentration bears straight relation with the electrode material. The phenol removal rate on the $\mathrm{Ti} / \mathrm{Ir}_{0.7} \mathrm{Ti}_{0.3} \mathrm{O}_{2}$ electrode is much faster if compared to the other electrode materials investigated. After $2 \mathrm{~h}$, almost $97 \%$ of the starting material is transformed with this electrode. On the other hand, the others electrode compositions need at least $5 \mathrm{~h}$ to achieve this rate. One of the reasons for such difference in electrode performance is that the $\mathrm{Ti} / \mathrm{Ir}_{0.7} \mathrm{Ti}_{0.3} \mathrm{O}_{2}$ electrode shows a much larger area when compared to the rutheniumderived electrodes. Thus, at the high current investigated, the morphological effects overcome the catalytic gain introduced by ruthenium under mild activation (CV).

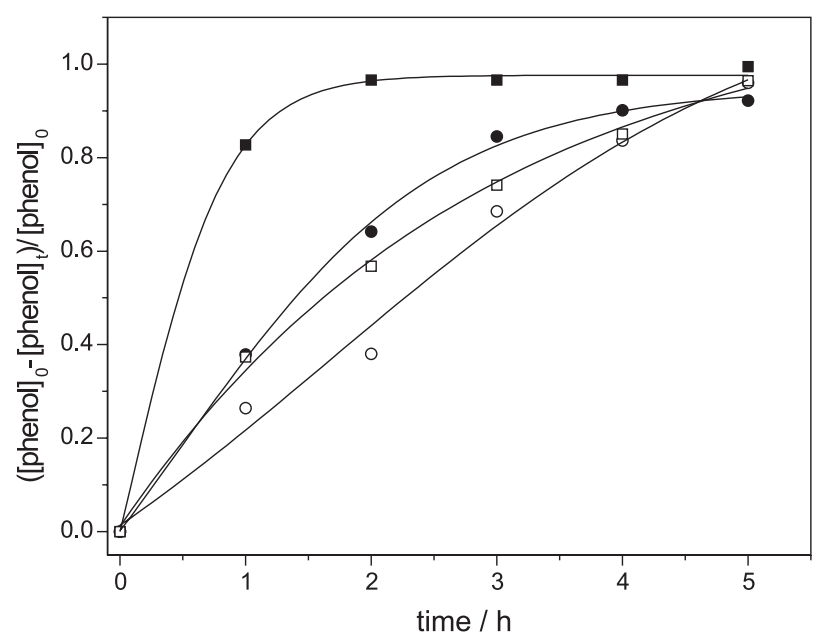

Figure 6. Plot of phenol normalized concentration decay as a function of the electrolysis time: $\mathrm{Ti} / \mathrm{Ru}_{0.3} \mathrm{Ti}_{0.7} \mathrm{O}_{2}(\bullet), \mathrm{Ti}^{-} \mathrm{Ru}_{0.3} \mathrm{Sn}_{0.7} \mathrm{O}_{2}(\mathrm{O})$ $\mathrm{Ti} / \mathrm{Ir}_{07} \mathrm{Ti}_{03} \mathrm{O}_{2}(\square)$ and $\mathrm{Ti} / \mathrm{Ir}_{07} \mathrm{Sn}_{03} \mathrm{O}_{2}(\square)$, in $\mathrm{NaClO}_{4} 1.0 \mathrm{~mol} \mathrm{~L}^{-1} ; v=$ $20 \mathrm{mV} \mathrm{s}^{-1} ; \phi=2 \mu \mathrm{m}, \mathrm{A}=2 \mathrm{~cm}^{2}, \mathrm{~T}_{\text {cal }}=450^{\circ} \mathrm{C}, \mathrm{C}_{\text {phenol }}=1 \mathrm{mmol} \mathrm{L}^{-1}, \mathrm{I}$ $=40 \mathrm{~mA} \mathrm{~cm}{ }^{2}$.

Figure 7 shows the plot of $\ln \left([\mathrm{phenol}]_{(\mathrm{t}) /}[\mathrm{phenol}]_{(0)}\right) v s$. time. Values for the pseudo-first order rate constant $\mathrm{k}_{\mathrm{s}} \mathrm{s}^{-1}$ (obtained as the slopes of the straight lines shown in Figure 7 for the first two h of electrolysis) and the kinetic constant for phenol oxidation $\mathrm{k}_{\mathrm{ph}} / \mathrm{m} \mathrm{s}^{-1}\left(\mathrm{k}_{\mathrm{ph}}=k \mathrm{~V} / \mathrm{A} ; \mathrm{V}\right.$ is the volume 
$\left(\mathrm{m}^{3}\right)$ and $\mathrm{A}$ is the anode area $\left.\left(\mathrm{m}^{2}\right)\right)$ are shown in Table 2. Analysis of this table confirms the results shown before. As the electrode material is modified, the rate of phenol oxidation changes. The following phenol consumption rate was observed: $\mathrm{Ti} / \mathrm{Ir}_{0.7} \mathrm{Ti}_{0.3} \mathrm{O}_{2}>\mathrm{Ti} / \mathrm{Ir}_{0.7} \mathrm{Sn}_{0.3} \mathrm{O}_{2} \sim \mathrm{Ti} /$ $\mathrm{Ru}_{0.3} \mathrm{Ti}_{0.7} \mathrm{O}_{2}>\mathrm{Ti} / \mathrm{Ru}_{0.3} \mathrm{Sn}_{0.3} \mathrm{O}_{2}$. In fact, these results show a straightforward connection between the morphological factors (number of electroactive sites available for reaction) and the overall rate of phenol oxidation. This is an apparent disagreement with results reported recently by Pelegrino et al. ${ }^{10}$ Those authors, founded for phenol electrooxidation that $\mathrm{Ti} / \mathrm{Ru}_{0.3} \mathrm{Ti}_{0.7} \mathrm{O}_{2}$ shows a markedly superior performance over $\mathrm{IrO}_{2}-\mathrm{Ta}_{2} \mathrm{O}_{5}$ electrodes. It is a difficult task to compare electrooxidation results once electrode composition, surface area, volume of solution and supporting electrolyte reported from different laboratories, most on the time, are not similar. However, the phenol removal rate obtained by us is similar to the results obtained by Pelegrino et al. ${ }^{10}$ or doped diamond electrodes. ${ }^{36}$ The introduction of $\mathrm{SnO}_{2}$, a well-know active anode for organic oxidation, ${ }^{3}$ in the binary mixture with $\mathrm{RuO}_{2}$ or $\mathrm{IrO}_{2}$, produces a slightly more active material for phenol oxidation. This can be explained by the enhancement of the OER reaction as $\mathrm{SnO}_{2}$ is introduced in the electrode composition.

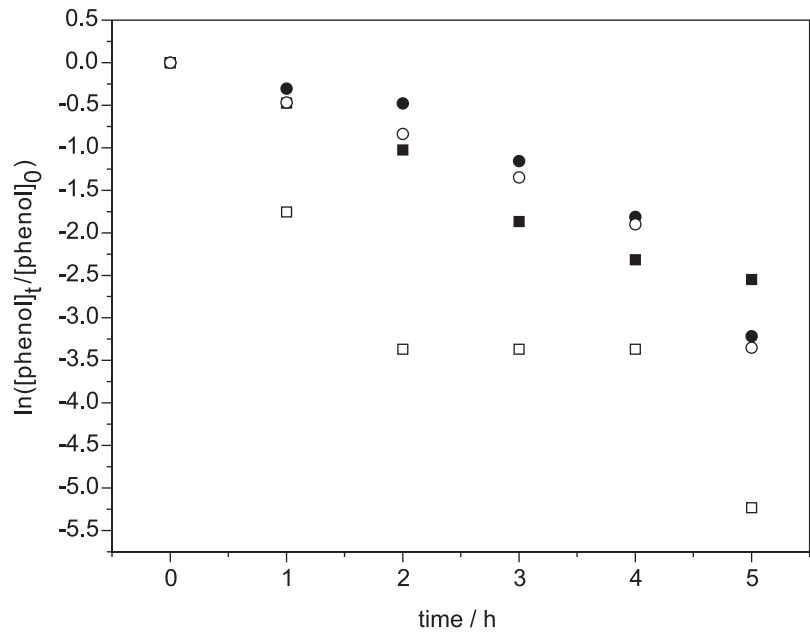

Figure 7. Logarithm of the decay of normalized concentration of phenol in function of electrolysis time for different electrode materials: $\mathrm{Ti} / \mathrm{Ru}_{0.3} \mathrm{Ti}_{0.7} \mathrm{O}_{2}(\mathbf{O}) ; \mathrm{Ti} / \mathrm{Ru}_{0.3} \mathrm{Sn}_{0.7} \mathrm{O}_{2}(\mathrm{O}) ; \mathrm{Ti} / \mathrm{Ir}_{0.7} \mathrm{Ti}_{0.3} \mathrm{O}_{2}$ ( $\left.\mathbf{\square}\right)$ and $\mathrm{Ti} / \mathrm{Ir}_{0.7} \mathrm{Sn}_{0.3} \mathrm{O}_{2}(\square)$; in $\mathrm{NaClO}_{4} 1.0 \mathrm{~mol} \mathrm{~L}^{-1} ; v=20 \mathrm{mV} \mathrm{s}^{-1}, \phi=2 \mu \mathrm{m}, \mathrm{A}$ $=2 \mathrm{~cm}^{2}, \mathrm{~T}_{\text {cal }}=450{ }^{\circ} \mathrm{C}, \mathrm{C}_{\text {phenol }}=1 \mathrm{mmol} \mathrm{L}^{-1}, \mathrm{I}=40 \mathrm{~mA} \mathrm{~cm}$.

Table 2. Kinectics results for electrodegradation of $1000 \mathrm{ppm}$ of phenol for different anodes composition and in $\mathrm{NaClO}_{4} 1.0 \mathrm{~mol} \mathrm{~L}-1$

\begin{tabular}{lcr}
\hline Electrode & $\mathrm{k} / \mathrm{s}^{-1}$ & \multicolumn{1}{c}{$\mathrm{k}_{\mathrm{ph}} / \mathrm{m} \mathrm{s}^{-1}$} \\
\hline $\mathrm{Ti} / \mathrm{Ru}_{0.3} \mathrm{Ti}_{0.7} \mathrm{O}_{2}$ & $1.42 \times 10^{-4}$ & $2.84 \times 10^{-3}$ \\
$\mathrm{Ti} / \mathrm{Ru}_{0.3} \mathrm{Sn}_{0.7} \mathrm{O}_{2}$ & $0.66 \times 10^{-4}$ & $1.32 \times 10^{-3}$ \\
$\mathrm{Ti} / \mathrm{Ir}_{0.7} \mathrm{Ti}_{0.3} \mathrm{O}_{2}$ & $5.12 \times 10^{-4}$ & $10.24 \times 10^{-3}$ \\
$\mathrm{Ti} / \mathrm{Ir}_{0.7} \mathrm{Sn}_{0.3} \mathrm{O}_{2}$ & $1.66 \times 10^{-4}$ & $3.32 \times 10^{-3}$ \\
\hline
\end{tabular}

\section{Product identification}

HPLC analyses of the intermediate products show that benzoquinone is the main product in the quinone portion. After ring opening, the main products are malic, malonic and tartaric acids. Besides these, two other non-identified byproducts were also detected in the aliphatic portion, in lower yields. The reaction profile of benzoquinone is shown in Figure 8. It can be seen that benzoquinone, an undesirable side-product that is as hazardous as phenol, is formed during the electrolysis, but it is further oxidized to the aliphatic acid portions. The ability to further oxidize benzoquinone after 5 hours of electrolysis follows a slightly different order from the one shown before for phenol: $\mathrm{Ti} / \mathrm{Ir}_{0.7} \mathrm{Ti}_{0.3} \mathrm{O}_{2}>\mathrm{Ti} / \mathrm{Ir}_{0.7} \mathrm{Sn}_{0.3} \mathrm{O}_{2} \cong \mathrm{Ti} / \mathrm{Ru}_{0.3} \mathrm{Sn}_{0.7} \mathrm{O}_{2}>$ $\mathrm{Ti} / \mathrm{Ru}_{0.3} \mathrm{Ti}_{0.3} \mathrm{O}_{2}$.

Table 3 shows the results for TOC in different current densities as a function of the material, investigated after 5 hours of electrolysis. TOC removal does not follow the behavior observed for $\mathrm{k}_{\mathrm{ph}}$. In fact, the most active material for complete mineralization of the intermediates formed is the $\mathrm{RuO}_{2}-\mathrm{TiO}_{2}$ electrode. A proper choice of material and current density values can promote TOC reduction as high as $80 \%$. This is a very meaningful result, if compared to degradation rates $(30-40 \%)$ previously reported for commercial oxide electrodes in acid medium. ${ }^{10,37}$ It is worthwhile to mention that at the lower phenol concentration investigated, no evidence for polymeric material was observed on the anode surface.

The lower efficiency observed for $\mathrm{CO}_{2}$ formation as one replaces $\mathrm{RuO}_{2}$ for $\mathrm{IrO}_{2}$ or introduce $\mathrm{SnO}_{2}$ in the binary compositions could be explained by the competition between the organic oxidation and OER reactions. At the high current applied both reaction compete for the same electroactive site on the electrode surface, and either: $(i)$ the introduction of $\mathrm{SnO}_{2}{ }^{30}$ or $(i i)$ area increase $\left(\mathrm{i} ; \mathrm{q}^{*}\right)$ enhance the performance for oxygen evolution reaction; one can expect that the desired reaction (total degradation of phenol) decreases. This feature makes the $\mathrm{Ti} / \mathrm{RuTiO}_{2}$ electrode more efficient to further oxidize the intermediates formed in phenol oxidation.

The analysis of the products formed is a good example of the selectivity one might obtain as the electrode material is changed. $\mathrm{Ru}-\mathrm{SnO}_{2}$ electrodes showed sightly lower phenol consumption rate compared with the other electrode material investigated; nevertheless, it promotes almost complete combustion of the starting material (75\%). To explain this fact we can speculate that the $\mathrm{CO}_{2}$ could be formed by an alternative route without passing through benzoquinone formation similar as proposed elsewhere. ${ }^{37}$ This makes this material a much better choice for waste 
treatment since it promotes low yields of the hazardous by-product (Benzoquinone) with higher formation of desired product $\left(\mathrm{CO}_{2}\right)$.

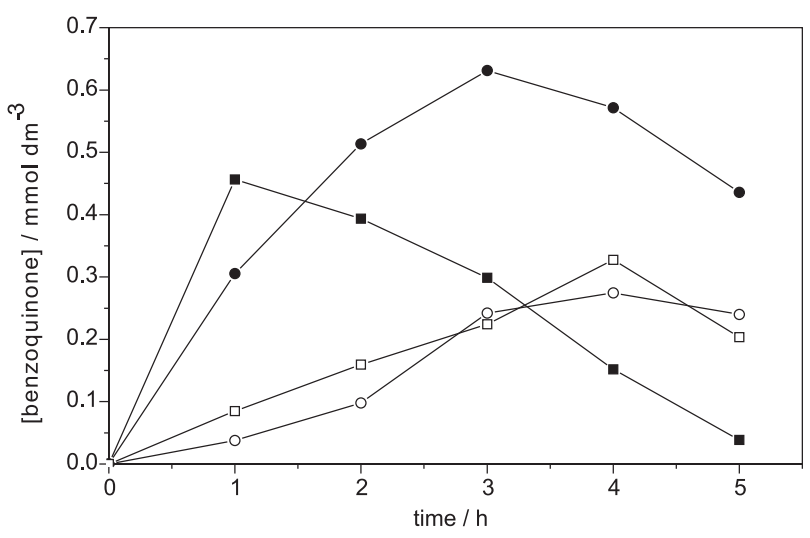

Figure 8. Benzoquinone concentration profile during electrolysis on different electrode materials: $\mathrm{Ti} / \mathrm{Ru}_{03} \mathrm{Ti}_{07} \mathrm{O}_{2}(-) ; \mathrm{Ti} / \mathrm{Ru}_{03} \mathrm{Sn}_{07} \mathrm{O}_{2}$ $(\mathrm{O}) ; \mathrm{Ti} / \mathrm{Ir}_{0.7} \mathrm{Ti}_{0.3} \mathrm{O}_{2}(\boldsymbol{\square})$ and $\mathrm{Ti} / \mathrm{Ir}_{0.7} \mathrm{Sn}_{0.3} \mathrm{O}_{2}(\square)$. Electrolyte: $\mathrm{NaClO}_{4}$ $1.0 \mathrm{~mol} \mathrm{~L}^{-1} ; v=20 \mathrm{mV} \mathrm{s}^{-1} ; \phi=2 \mu \mathrm{m} ; \mathrm{A}=2 \mathrm{~cm}^{2} ; \mathrm{T}_{\text {cal }}=450{ }^{\circ} \mathrm{C}, \mathrm{C}_{\text {phenol }}$ $=1 \mathrm{mmol} \mathrm{L}^{-1}, \mathrm{I}=40 \mathrm{~mA} \mathrm{~cm}$.

Table 3. Dependence of TOC with electrode material and current density for solution initial containing $1000 \mathrm{ppm}$ of phenol in $\mathrm{NaClO}_{4}$ $1.0 \mathrm{~mol} \mathrm{~L}^{-1}$

\begin{tabular}{|c|c|c|c|}
\hline \multirow[b]{2}{*}{$\begin{array}{l}\text { Nominal } \\
\text { composition }\end{array}$} & \multicolumn{3}{|c|}{$\%$ NPOC reduction } \\
\hline & 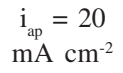 & $\begin{array}{c}\mathrm{i}_{\text {ap }}=40 \\
\mathrm{~mA} \mathrm{~cm} \mathrm{~cm}^{-2}\end{array}$ & $\begin{array}{l}\mathrm{i}_{\text {ap }}=80 \\
\mathrm{~mA} \mathrm{~cm} \mathrm{~cm}^{-2}\end{array}$ \\
\hline $\mathrm{Ti} / \mathrm{Ru}_{0.3} \mathrm{Ti}_{0.7} \mathrm{O}_{2}$ & - & 39 & 80 \\
\hline $\mathrm{Ti} / \mathrm{Ru}_{0.3} \mathrm{Sn}_{0.7} \mathrm{O}_{2}$ & 14 & 24 & 75 \\
\hline $\mathrm{Ti} / \mathrm{Ir}_{0.7} \mathrm{Ti}_{0.3} \mathrm{O}_{2}$ & - & 23 & 50 \\
\hline $\mathrm{Ti} / \mathrm{Ir}_{0.7} \mathrm{Sn}_{0.3} \mathrm{O}_{2}$ & - & 11 & 18 \\
\hline
\end{tabular}

\section{Conclusions}

This paper shows that for the binary $\mathrm{Ti} / \mathrm{Ir}_{0.7} \mathrm{Sn}_{0.3} \mathrm{O}_{2}$ composition, the decomposition of polymeric precursors is an appropriate route to avoid Sn loss during thermal treatment. The prepared oxide films showed high surfaceactive area and proper control of stoichiometry.

Changing $\mathrm{TiO}_{2}$ to $\mathrm{SnO}_{2}$ promotes an increase in the apparent roughness of the electrode. For Ru-based electrodes, introduction of $\mathrm{SnO}_{2}$ produces a more active material to OER.

Phenol oxidation was used as a probe reaction to carry out a systematic investigation of the electrocatalytic activity of DSA-type anodes with nominal compositions equals to $\mathrm{Ti} / \mathrm{Ru}_{03} \mathrm{M}_{07} \mathrm{O}_{2}$ and $\mathrm{Ti} / \mathrm{Ir}_{0.7} \mathrm{M}_{03} \mathrm{O}_{2}(\mathrm{M}=\mathrm{Ti}$ and $\mathrm{Sn})$, at $1.0 \mathrm{~mol} \mathrm{~L}^{-1} \mathrm{NaClO}_{4}$. Bulk electrochemical oxidation of phenol depends on the nature of the anode. In a twocompartment cell, the final oxidation products observed were $\mathrm{CO}_{2}$, benzoquinone, malic, malonic and tartaric acids.
The observed phenol removal rate is as follows: Ti/ $\mathrm{Ir}_{0.7} \mathrm{Ti}_{0.3} \mathrm{O}_{2}>\mathrm{Ti} / \mathrm{Ir}_{0.7} \mathrm{Sn}_{0.3} \mathrm{O}_{2} \sim \mathrm{Ti} / \mathrm{Ru}_{0.3} \mathrm{Ti}_{0.7} \mathrm{O}_{2}>\mathrm{Ti} /$ $\mathrm{Ru}_{0.3} \mathrm{Sn}_{0.3} \mathrm{O}_{2}$. The best material for initial phenol and benzoquinone consumption ( $\mathrm{Ti} / \mathrm{Ir}_{0.7} \mathrm{Sn}_{0.3} \mathrm{O}_{2}$ and $\mathrm{Ti} /$ $\mathrm{Ir}_{0.7} \mathrm{Ti}_{0.3} \mathrm{O}_{2}$, respectively) fails to further oxidize the acid portion of the formed intermediates Highest removal of TOC was observed for $\mathrm{Ti} / \mathrm{Ru}_{0.3} \mathrm{Ti}_{0.3} \mathrm{O}_{2}$, confirming that this material is capable of almost completely mineralizing (80 $\%$ TOC removal) phenol in 5 hours, for both current densities investigated. This can be speculated as evidence that total combustion of phenol might follow an alternative route without passing through benzoquinone formation was observed for $\mathrm{RuO}_{2}-\mathrm{SnO}_{2}$ electrodes.

\section{Acknowledgements}

This study was supported by FAPESP (01/10338-1) and CNPq (521536/97-9) foundations. The fellowships from CAPES (P.D.P. Alves) and FAPESP (M. Sapgnol) are greatly acknowledged. M. V. Carlos (Depto. Química FFCLRP-USP) and M. Ferreira's (IQSC-USP) help with the HPLC analyses is greatly appreciated.

\section{References}

1. Rajeshwar, K, Ibanez, J.G., Environmental Electrochemistry: Fundamentals and Applications in Pollution Abatement, Academic Press, Inc.: USA, 1997.

2. Houk, L. L; .Johnson, S. K.; Feng, J.; Houk, R. S.; Johnson, D. C.; J. Appl. Electrochem. 1998, 28, 1167.

3. Simond, O.; Schaller, V.; Comninellis, Ch.; Electrochim. Acta 1997, 42, 2009.

4. Bock, C.; MacDougall, B.; J. Electrochem. Soc. 1999, 146, 2925.

5. Azzam, M. O.; Al-Tarazi, M.; Tahboub, Y.; J. Hazardous Mat. 2000, B75, 99 .

6. Polcaro, A. M.; Palmas, S.; Ind. Eng. Chem. Res. 1997, 36, 1791.

7. Savall, A.; Chimia 1995, 49, 23.

8. De Angelis, F.; Corso, C. R.; Bidoia, E. D.; Moraes, P. B.; Domingos, R.; Rocha-Filho, R. C.; Quim. Nova 1998, 21, 20.

9. Brazil, Resolution \# 20 from Conselho Nacional do meio Ambiente, CONAMA, 1986. http://www.lei.adv.br/02086.htm; accessed at January 27/2004.

10. Pelegrino, R. L.; Di Iglia, R. A.; Sanches, C. G.; Avaca, L. A.; Bertazzoli, R.; J. Braz. Chem. Soc. 2002, 1, 60.

11. Flezsar, B.; Ploszynska.J.; Electrochim. Acta 1985, 30, 31.

12. Comninellis, Ch.; Pulgarin, C.; J.Appl. Electrochem. 1991, 21, 703 .

13. Amouzegar, K.; Savadogo, O.; Electrochim. Acta 1998, 43, 503. 
14. Tahar, N. B.; Savall, A.; J.Electrochem.Soc. 1998, 145, 3427.

15. Comninellis, C. In Enviromental Electrochemistry; Sequeira C.A.C. ed., Elsevier: Amsterdam, 1994.

16. Comninellis, C.; Electrochim. Acta 1994, 39, 1857.

17. Garavaglia, R.; Mari, C.M.; Trasatti, S.; Surf. Technol. 1984, $23,41$.

18. Angelinetta, C.; Trasatti, S.; Atanasoska, Lj.; Atanasoski, R.T.; J. Electroanal. Chem. 1986, 214, 535.

19. Lassali, T. A. F.; Bulhões, L. O. S.; Abeid, L. M. C.; Boodts, J. F. C.; J. Electrochem. Soc. 1997, 144, 3348.

20. Comninellis, C.; Vercesi, G. P.; J. Appl. Electrochem. 1991, $21,136$.

21. Pechini, M.P.; Adams, N.; US Patent 3,330,697 1967.

22. Olivi, P.; Pereira, E.C.; Longo, E.; Varela, J.A..; Bulhões, L.O.S.; J. Electrochem. Soc. 1993, 140, L81.

23. Besso, M. M.; US Patent, 3,213,120 1965.

24. Lassali, T. A. F.; Boodts, J. F. C.; Bulhões, L. O. S.; J. NonCryst. Solids 2000, 273, 129.

25. Forti, J. C.; Olivi, P; De Andrade, A. R.; Electrochim. Acta 2001, 47, 913.

26. Ardizzone, S. ; Fregonara, G.; Trasatti, S.; J. Electroanal. Chem, 1989, 266, 191.
27. Blouim, M.; Guay, D.; J. Electrochem. Soc. 1997, 144, 573.

28. Murakami, Y.; Ito, M.; Kaji, H.; Takasu, Y.; App. Surf. Sci. 1997, 121/122, 314.

29. Trasatti, S.; Petrii, O. A.; Pure Appl. Chem. 1991, 63, 711.

30. Onuchukwu, A.; Trasatti, S.; J. Appl. Electrochem. 1991, 21, 858.

31. Trasatti, S.; Electrocatalysis 2000, 45, 2377

32. Rodrigo, M. A.; Michaud, P. A.; Duo, I.; Panizza, M.; Cerisola, G.; Comninellis, Ch.; J. Electrochem. Soc. 2001, 148, D60.

33. De Andrade, A. R.; Donate, P. M.; Alves, P. P. D.; Fidellis, C. H. V.; Boodts, J. F. C.; J. Electrochem. Soc. 1998, 145, 3839.

34. Bock, C.; MacDougall, B.; J. Electroanal. Chem. 2000, 491, 48 .

35. Zanta, C. L. P. S.; De Andrade, A. R.; Boodts, J. F. C.; Electrochim. Acta 1999, 44, 3333

36. Torres, R. A.; Torres, W.; Peringer, P.; Pulgarin, C.; Chemosphere 2003, 50, 97.

Received: October 13, 2003 Published on the web: September 9, 2004

FAPESP helped in meeting the publication costs of this article. 